\title{
Proteina ugariko dietak: lagunak ala etsaiak? Artikuluen berrikusketa
}

\author{
High Protein Diets: Allies or Enemies? Article Review
}

\author{
Aitor Garcia-Barandiaran ${ }^{1}$ \\ ${ }^{1}$ Gurutzetako Unibertsitate Ospitalea. Nefrologia Zerbitzua. \\ barandi_93@hotmail.com
}

\section{Laburpena}

Oso hedatua dago proteinek, kopuru handitan hartuta zein bestela ere, giltzurrunen kaltea ekartzen dutela. Jakina da proteinaren ekarpenaren murrizketak giltzurrun-gutxiegitasun diabetikoa zein ezdiabetikoaren aurrera egitea atzeratzen dituela, baita hauek bere baitan dakartzaten ondorioak ere. Beste alde batetik, proteinek kirol-errendimendua hobetzen eta muskulu-masa sortzen laguntzen dute, eta hainbat saiakuntza klinikotan agertu dira, proteinek kirolari osasuntsuetan eragiten dituzten aldaketak parametro funtzionaletan eta biokimikoetan. Orain arte, bi argudio kontrajarri daude proteinen kontsumoaren gainean: batzuek giltzurrunak kaltetzen dituztela, besteek eragin negatiborik ez dutela. Biak bateratuz gero, esan daiteke jada gaixo dagoen giltzurrunean proteinen kontsumo handiak kaltearen aurrera egitea sustatzen duela, pertsona osasuntsuetan ordea, inolako kalterik sortzen ez duelarik. Lehenaren babesleek proteina-kontsumoarekin kontuz ibiltzeko, eta beronen murrizpenaren aldeko jarrera dute; bigarrenek ordea kontsumo librea bultzatzen dute, baita altua ere, helburuak lortzeko bidean kalterik ez omen du sortzen eta. Baieztapen hauek zentzuzkoak diren ala ez argitzeko hainbat datu eta iturri bildu dira berrikuspen honetan, animalia zein gizakietan (osasuntsu daudenak, gaixo egoteko arriskuan daudenak, zein gaixorik daudenak) buruturiko saiakuntzak, gaiaren inguruan hipotesi berriak eta erantzun posibleak mahaiaren gainean jartzeko.

Gako-hitzak: giltzurruna, proteinak, dieta, kaltea, giltzurrun-kaltea, giltzurrun-gutxiegitasuna, kirola, glomerulua, hiperfiltrazioa

\section{Abstract}

The belief that, either in high intake or in general, protein consumption causes kidney damage is widely extended. It is known that protein intake limitation helps reducing diabetic and non-diabetic $C K D$, and their associated consequences. On the other hand, protein helps in sport performance and building muscle mass, and some clinical trials have shown what protein intake causes at functional and biochemical parameters in healthy sportsmen and women. There are two opposite arguments about protein intake: some say it causes kidney damage, others say that there is no negative impact. Putting them together, one could tell that protein intake in a kidney that is already malfunctioning may lead to its destruction, while there is no risk of harm in those that are healthy. Defenders of the first argument support that there is a need to be careful with protein quantity, and that it should be reduced; those who support free protein consumption, even high protein intake, argue that it apparently doesn't bring kidney damage. In this review considerable data and sources were gathered, such as clinical trials in animals and humans (healthy, pre-illness stage and ill ones), in order to clarify if those statements are reasonable or not, and to put new hypothesis and possible answers on the table.

Keywords: kidney, protein, diet, injury, kidney injury, kidney disease, sport, glomerulus, hyperfiltration 
Bidalia: 2019ko urtarrilaren 24an.

Onartua: 2019ko maiatzaren 21ean.

https://doi.org/10.26876/osagaiz.1.2019.228

\section{Materiala eta metodoak}

Artikuluen berrikusketa egiteko Pubmed online datu-basea erabili da. "Dietary protein intake", "kidney function", "high protein intake" eta "kidney disease" hitzak erabili dira bilatze-lana egiteko. Filtrorik ez da ipini, baina testu osoa eskuragarri duten, 10 urte baino gutxiagoko (20 artikulutik, 14 2013. urtetik aurrerakoak dira), gizakiengan egindako ikerketak batzen dituzten artikuluei eman zaie lehentasuna. Proteinen kontsumoari egozten zaion glomeruluen iragazte-tasaren handipena azaltzeko, antzekoak izan daitezkeen beste bi egoera planteatu dira ondoren: obesitatea eta haurdunaldia. Hauek bilatzeko "pregnancy" eta "physiology" hitzak erabili dira, eta nabarmendutako artikuluen artean egin da hautaketa. Obesoen artean "obese" eta "protein intake" hitzak erabili dira, eta diabetes mellitusik (DM) ez dutenen ikerketak hautatu dira.

Batez ere gizaki osasuntsuen giltzurrunetan edota giltzurrunaren funtzioan dagoen efektua ikertu nahi izan da, eta hauen artean kirolarien eta sedentarioen artean alderik egon ote daitekeen. Bestalde, giltzurruneko gaixotasuna ez duten baina patologia aurreko egoeran dauden pertsonekin eta giltzurrunak gaixorik dituzten pertsonekin alderatu nahi izan da.

Proteinen kontsumoa handitzat hartzeko ez da muga zehatzik ezarri, gaur egun muga hori zehazteko adostasunik ez baitago. "High Protein" kontzeptua oso aldakorra da. Zenbait ikerketatan dietaren kalorien $\%>30$ bezala deskribatu da, beste batzuetan $>1,5-2 \mathrm{~g} / \mathrm{kg} /$ eguneko moduan. Ez dago ondo zehaztuta autoreek zer hartu duten proteina ugariko dietatzat. Askotan (batez ere hilkortasuna erakutsi duten horietan), proteina ugariko gehi karbohidrato gutxiko dietak agertu dira. Beraz, proteinen guztizko kantitatea ez ezik, hauen proportzioa ere aintzat hartu da zenbaitetan. Aipatu beharra dago kontuan hartu nahi dena proteinen ingestio osoa dela, ingestio honetarako proteina osagarriak (sintetikoak) hartuta edo janariarekin hartutakoak diren alderatu gabe.

\section{Sarrera}

la bi hamarkada dituen XXI. mende honetan, fitness eta kirol-errendimenduari lotu diren eta gosearen kontrolerako eskaintzen duten asetzeko gaitasunari esker pisua galtzeko erreminta moduan erabili diren proteina ugariko dietak apurka-apurka ezagutzera eman dira. Honekin batera, zenbait jarrera agertu dira, proteinen gehiegizko kontsumo batek gorputzean, konkretuki giltzurrunetan kaltea sor dezakeen harira. Gaixorik dauden pertsonetan dietako proteina kantitatea murriztu egin ohi da, giltzurrunen kaltearen aitzinamendua moteltzen duelako. Baina oraindik jakiteke dago, osasuntsu diren edo oraindik gaixotasunik garatu ez duten pertsonengan, eta batez ere kirolariengan, proteina asko kontsumitzeak kaltea sortzen duen.

Kirola egiten aurreratu zein adituak ez direnek ( $>2$ urtez erresistentzia edo beste motatako entrenamenduren bat egiten dutenak) ariketa fisikoa egiten hasten direnean gorputzaren konposizioa aldatu egingo zaie. Orokorrean, ohikoa da muskulu-masa handitzea gantza galtzearekin batera, proportzio berean emango ez bada ere. Hau, hasierako egokitze fisiologikoaz gain, izan liteke mendebaldeko gizartean gehiegizko proteina-kontsumoak ere laguntzea: gure dietaren \% 15-20 izan behar du proteinak, giden eta erakundeen gomendioen arabera, baina gure gizartean erraz gainditzen dugu portzentaje hori. Gauzak horrela eta dieta egokia eginda, kirolariek bezala kalorien kontsumoa igotzea zentzuzkoa dirudi, muskulu-masa handitu eta errendimendua hobetzeko. Bide beretik gantzen, karbohidratoen edota proteinen proportzioa handitu gabe, guztizko proteinen kopuruak gora egingo du.

Adibide bat jartzeko, astean 4-5 aldiz kirola egiten duen 25 urte, $75 \mathrm{~kg}$ eta $180 \mathrm{~cm}$-ko pertsona batek, Harris Benedict formularen arabera $2.800 \mathrm{kcal}$ inguru beharko lituzke. Proteinak dietaren \% 15-20 
badira, erraza da 135-150g proteina kontsumitzea eguneko. Horrek esan nahi du 1,7-2 g/kg/eguneko kontsumitzen direla, erraz. Kirolariengan gerta daitezke egoera hauek.

Proteina kantitate handietan kontsumitzeak hainbat baldintzapean zenbait nahasmendu eragiten ditu; glomeruluetako hiperfiltrazio eta hiperemia, giltzurruneko gaixotasun kronikoaren (GGK) aurrerapena, proteinuria handitzea, diuresiaren, natriuresiaren, kaliuresiaren eta odol-presioaren aldaketak bultzatzeaz gain, nefrolitiasiaren (giltzurrun harrien) arrisku handiagoa ekar dezake beste hainbat aldaketa metabolikoren artean (1).

Proteinek sor ditzaketen efektuen arteko alderapena hurrengo taulan laburtu da (1. taula).

\section{1. taula}

\begin{tabular}{|c|c|}
\hline Proteina ugariko dieten ALDE & Proteina ugariko dieten AURKA \\
\hline $\begin{array}{l}\text { - Muskulu-masaren handipena, eta honek } \\
\text { dakarren indar handiagoa aplikatzeko ahalmena. }\end{array}$ & $\begin{array}{l}\text { - Giltzurruneko gaixotasun kronikoa duten } \\
\text { pertsonetan giltzurrunaren funtzioaren galera } \\
\text { azkartzen dute. }\end{array}$ \\
\hline $\begin{array}{l}\text { - Muskulu-masa mantentzea (pertsona nagusiei } \\
\text { bizi-kalitate eta autonomia-maila hobe } \\
\text { diezaieke). }\end{array}$ & $\begin{array}{l}\text { - Zalantzazkoa da pertsona osasuntsuengan } \\
\text { Giltzurruneko Gaixotasuna sor dezaketen. }\end{array}$ \\
\hline - Kirol-errendimendu hobea. & $\begin{array}{l}\text { - Hezueria (batez ere animalia jatorriko proteina } \\
\text { den purinak). }\end{array}$ \\
\hline \multirow{2}{*}{$\begin{array}{l}\text { - Gosearen aldetik asetasuna eskaintzea } \\
\text { (proteinak pisua galtzeko erreminta ona dira). }\end{array}$} & - Giltzurruneko hiperfiltrazioa. \\
\hline & -Nefrolitiasi arriskua. \\
\hline
\end{tabular}

\section{Giltzurrun-funtzioaren eta giltzurrun-gaixotasunaren definizioa}

Jakina da giltzurrunek gorputzean betetzen dituzten ondorengo funtzioak: gorputzeko hondakinen eta substantzien iraizketa, likidoen bolumenaren kontrola (eta honela osmolalitatearen eta odolpresioaren kontrola), azido-base orekaren kontrola eta hormonen sintesia besteak beste.

Aintzat hartuta bihotz-gastua, gastu horretan giltzurrunek jasotzen duten proportzioa, eta baita ere odoleko plasma portzentajearen eta glomeruluetatik Bowman kapsulara pasako den plasma kopurua, kalkulatu da giltzurrunaren batez besteko iragazketa-tasa $120 \mathrm{ml} / \mathrm{min}$ dela.

Glomeruluak nefronarekin kontaktuan dauden eta gernu-iragazketaren lehen pausoa osatzen duten odol-hodien korapilo mikroskopikoak dira (1. irudia). 
1. irudia Glomerulua, gorriz, Bowman kapsulak inguratua. Iturria: https://es.wikipedia.org/wiki/Glom\%C3\%A9rulo renal

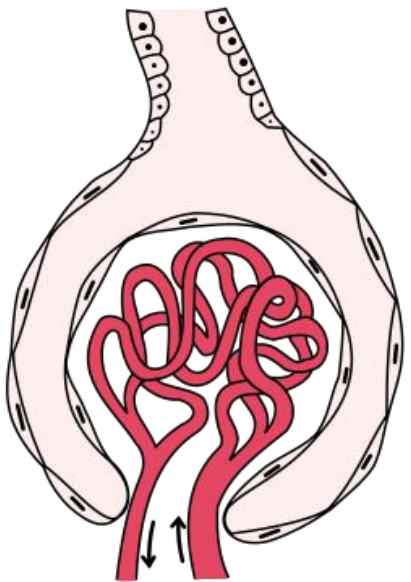

Giltzurrunen lana kuantifikatzeko glomeruluen iragazketa-tasa neurtzen da, hau da, glomeruluetara pasatzen den plasma kantitatea.

Glomeruluen iragazketa-tasa (GFR) kalkulatzeko 24 orduko gernua batu eta aztertzea dugu metodo onena. Oso metodo neketsua denez gero, horren ordez formula matematikoak erabiltzen dira giltzurrunen glomerulu-iragazketaren tasa kalkulatzeko. Erabilienak MDRD4, MDRD6 eta CKD-EPI dira. Azken horrek estimazio hobea ematen du giltzurruneko gaixotasun kronikoa duten pertsonetan.

Giltzurrunaren unitate funtzionala nefrona da, giltzurrun-korpuskuluak (glomeruluak eta Bowman kapsula) eta giltzurrun-hodiek osatua. Gizonezkoek 900.000 nefrona inguru dituzte guztira eta emakumezkoek 700.000. Nefrona horiek osatzen dute giltzurruneko erreserba funtzionala. Denborarekin, urteak betetzen diren heinean, erreserba funtzional hau jaitsi egiten da apurka, eta giltzurrunak bere funtzioak betetzeko duen ahalmena gutxitu egiten da. Aldaketa hori fisiologikotzat hartzen da, baina zenbait egoeratan giltzurrunaren funtzio-galera hori azkartu egiten da.

\subsection{Giltzurrun-gutxiegitasuna}

Odoleko produktu nitrogenatuen hondakinak giltzurrunaren bidez kanporatzeko ahalmena gutxituta dagoenean giltzurrun-gutxiegitasun baten aurrean gaudela esan dezakegu (2). Gutxiegitasun hori akutua (orduetan edo egunetan ezarria), azpiakutua (aste batzuen buruan) edo kronikoa (hilabetetan) bezala sailkatu daiteke.

Gorputzeko likidoen bolumena, homeostasia, azido-base oreka, oreka hidroelektrolitikoa edo kreatininaren kontzentrazioa euren tarte egokian mantentzeko gaitasuna galtzen denean ere, egoerari giltzurrun-gutxiegitasuna deituko zaio. Eguneko $<500 \mathrm{ml}$ gernu kanporatzen denean oliguria deritzo, eta aldiz anuria $<100 \mathrm{ml}$ kanporatzen badira.

Giltzurruneko gaixotasun kronikoaren (GGK) definizioa giltzurrunaren funtzioaren galera edo gutxitzea da, giltzurrunaren iragazketa-tasa $<60 \mathrm{ml} / \mathrm{min} / 1,73 \mathrm{~m}^{2}$ denean edo giltzurrun-kaltearen markatzaileak agertzen direnean, 3 hilabete edo gehiagotan zehar. Aipatutako fenomenoa giltzurrunaren biopsia batean aldaketa histologikoak behatuz ikus daiteke, baita giltzurruneko kaltea adierazten duten markatzaileak neurtuta ere (albuminuria edo proteinuria, gernu-sedimentuen nahasmenduak edo irudi-probetan aldaketak ikusita). 
Munduko herrialde garatuetan hogeita hamar urte baino gehiagoko pertsonen artean \% 7,2ko prebalentzia du. Espainian populazioaren \% 10ak pairatzen du gaixotasuna, 60 urtetik gora \% 20ra iristen delarik, eta askotan azpidiagnostikatua izaten da (3). Giltzurrunak berak pairatzen duen gaixotasunak gorputz osoan izango ditu ondorioak, bihotzean, odolean, eta hezurretan besteak beste.

GGKren eragileen artean nefropatia diabetikoa, nefroangiosklerosia, glomeruluen gaixotasun primario edo sekundarioa, giltzurruneko gaixotasun hereditarioak edo jaiotzetikoak, nefropatia interstizialak, gernu-bidearen buxadura kronikoa (litiasia barne), gernu-bideko infekzio errepikatuak, gaixotasun sistemikoak (lupus, baskulitis, mieloma...) aurki ditzakegu. Askotan faktore hauetako batek baino gehiagok parte hartuko dute, arazoa areagotuz.

\section{Giltzurrun-iragazketa handitzen duten egoerak}

Badaude giltzurrunetako glomerulu-iragazketaren tasa (GIT) handitzen duten zenbait kasu. Egoera hori fisiologikoa edo patologia aurrekoa izan daiteke. Giltzurrunek autorregulazio-ahalmena dute, eta gorputzaren fisiologiaren ohiko gorabeherek ez dute GIT aldatzen. Beraz, GIT aldatzen den egoeretan patologia dagoela pentsa daiteke edo giltzurrunek ahalmena galdu dutela. Hala ere, ez da beti horrela gertatzen.

Haurdunaldian adibidez, GIT \% 50 handitu egiten da egoera basalarekin alderatuta. Giltzurruneko plasma-fluxuak bere aldetik \% 80an egiten du gora (4). Egarriaren eta ADHren atalasea jaitsi egiten dira nabarmen. Beraz, nahiz eta eritrozitoen, plasma-zelulen, ioien eta proteinen kopuru totala igo, hauen kontzentrazioa jaitsi egiten da eta osmolalitatea zein sodioaren kontzentrazioa txikiak izaten dira. Aldaketa horiek, beste batzuen artean, progesteronak (eta baliteke karenak ere) eragindakoak dira.

Era berean, badaude giltzurrun-filtrazioa handitzen duten beste zenbait egoera, eta horietan iragazketa-tasa handitzen da, baina egoera hori kronifikatuz gero, azkenean moldapen-mekanismoek huts egiten dute, nefronetan kaltea eta nekrosi/fibrosia ekarriz. Hauen artean daude zahartzearen prozesu naturala, giltzurrun bakarra izatea / transplantea / giltzurrun-erreserba funtzional urria, hipertentsio arteriala, diabetes mellitusa (DM) eta obesitatea (5).

Egoera horietan, lehen fasean iragazketa-tasa handitu egiten da hainbat mekanismoren parte hartzearen ondorioz (errenina-angiotentsina-aldosterona [EAA] sistema, glomeruluan presio hidrostatiko handitua...). Fluxuaren handipenak odol-hodi txikietan sortzen du kalte aurrena: paretaren aurkako presioak ehunaren haustura mikroskopikoak ekartzeaz gain inflamazioa, zelulen erreparazioak eta immunitate-erantzunak egoki izateari uzten diotenean, eta sortutako hausturak orbaindu egiten dira, fibrosia sortuz. Denborak aurrera egin ahala, eta mekanismo hauen aktibitatea eteten ez denez, apurka-apurka glomeruluen eta nefronen kaltea eta aipatutako ondoriozko fibrosia agertuko dira. Onartzen da, beraz, hasierako glomerulu-hiperfiltrazioak patologia aurreko egoera iragartzen duela.

\section{Proteinak eta giltzurruneko kaltea}

Giltzurrun-iragazpena handitzea egoera fisiologikoan zein patologia aurrekoan gerta daitekeela ikusi da. Proteina ugariko dietak ere sartzen dira multzo honetan, dieta horiek giltzurrun-iragazpenaren tasa handitzen dutela ikusi baita.

GITren handipena ikertzeko garaian, proteinen papera zein den aztertu izan da. Zenbait idazlek, proteina ugariagoren ingestioak dakarren GITren handipena haurdunaldian gertatzen denarekin alderatu dute, baina ez da baieztatu mekanismo bera dutenik. Proteinek hiperfiltrazioa eta hodizabalkuntza sortzeko duten ahalmenaren mekanismoa ez da argi ezagutzen (6), nahiz eta zenbait 
ikerketek NO, TGF eta hainbat hodi-zabaltzaileri egotzi dioten efektua. Dena dela, emaitzetan gorabehera asko dago, askotan parametroak neurtzeko erabili diren tekniken arteko desberdintasunak direla medio.

Literaturan ugari dira dietako proteinen ingestioak eta obesitateak GIT eta albuminuria handitzen duela jasotzen dituzten artikuluak. Oso obesoak diren norbanakoetan $120 \mathrm{ml} / \mathrm{min}$-ko baino GIT askoz altuagoak topatzea ez da ezohikoa, kasu batzuetan $200 \mathrm{ml} / \mathrm{min}$-ra hel daitekeelarik. Era honetan, obesitateak berak (proteinen gehiegizko kontsumorik gabe) giltzurrun-hiperfiltrazioa sortzen duela ikusi da, batez ere proteinak GITn duen eragina askoz ere txikiagoa dela ikusi delako. Proteina ugari kontsumitzeak GITn $5+6 \mathrm{ml} / \mathrm{min}$-ko handipena dakarrela ikusita (2. taula), ez da nahikoa obesitateak sortzen duen hiperfiltrazioa azaltzeko (5).

2. taula Dietako proteinen efektuak giltzurruneko eta metabolismoko parametroetan (5). Iturria: Friedman AN et al. Independent influence of dietary protein on markers of kidney function and disease in obesity. Kidney Int. 2010; 78(7):693-7.

\begin{tabular}{|c|c|c|c|c|}
\hline & $\mathrm{HP}^{\mathrm{a}}$ & LPa $^{a}$ & Difference $^{b}$ & $P$-value ${ }^{c}$ \\
\hline$N$ & 17 & 17 & - & - \\
\hline Weight (kg) & $120 \pm 29$ & $120 \pm 29$ & $0 \pm 2$ & 0.977 \\
\hline Dietary protein intake ( $g /$ day) & $99 \pm 23$ & $50 \pm 14$ & $49 \pm 24$ & $<0.001$ \\
\hline GFR (ml/min) & $114 \pm 25$ & $109 \pm 26$ & $5 \pm 6$ & 0.005 \\
\hline Serum creatinine (mg/dl) & $0.75 \pm 0.14$ & $0.76 \pm 0.16$ & $-0.01 \pm 0.09$ & 0.580 \\
\hline Serum cystatin C (mg/l) & $0.83 \pm 0.16$ & $0.86 \pm 0.20$ & $-0.03 \pm 0.10$ & 0.270 \\
\hline 24 h urine protein (mg/day) & $188 \pm 73$ & $173 \pm 84$ & $15 \pm 88$ & 0.538 \\
\hline $24 \mathrm{~h}$ urine albumin $(\mathrm{mg} / \mathrm{day})^{d}$ & $9(3,30)$ & $11(3,59)$ & $-1(-51,16)$ & 0.147 \\
\hline $24 \mathrm{~h}$ urine urea $(\mathrm{g} / \mathrm{day})$ & $13.8 \pm 3.5$ & $6.0 \pm 2.1$ & $7.8 \pm 3.9$ & $<0.001$ \\
\hline $24 \mathrm{~h}$ urine creatinine ( $g /$ day) & $1.6 \pm 0.4$ & $1.6 \pm 0.6$ & $0.1 \pm 0.4$ & 0.533 \\
\hline BUN (mg/dl) & $14 \pm 4$ & $7 \pm 3$ & $7 \pm 4$ & $<0.001$ \\
\hline Systolic blood pressure $(\mathrm{mm} \mathrm{Hg})$ & $128 \pm 13$ & $128 \pm 11$ & $0 \pm 11$ & 0.872 \\
\hline Diastolic blood pressure $(\mathrm{mm} \mathrm{Hg})$ & $74 \pm 9$ & $74 \pm 7$ & $0 \pm 7$ & 0.962 \\
\hline Fasting glucose $(\mathrm{mg} / \mathrm{dl})$ & $89 \pm 17$ & $90 \pm 9$ & $-1 \pm 12$ & 0.809 \\
\hline HOMA score ${ }^{d}$ & $3.9(1.3,13.3)$ & $4.0(0.8,10.3)$ & $0.3(-2.6,9.7)$ & 0.435 \\
\hline
\end{tabular}

\subsection{Animalietatik zer dakigun}

Animalietan badago frogarik proteina ugariko dietek giltzurrunei kalte egiten dietela pentsatzeko. Arratoietan kontrol-taldearekin alderatuta hamazazpi hilabetez egindako ikerketa batean, proteina ugariko taldeko arratoiek giltzurrunak \% 17 astunagoak zituzten $(p<0,0001)$, proteinuria hirukoitza $(p<0,0001)$ eta kreatinina-argitze \% 27 handiagoa $(p=0,0012)$. Honekin batera proteina ugariko taldeak glomerulu handiagoak ( $p<0,0001)$ eta glomeruluen esklerosia $(p=0,0003)$ azaldu zituen kontrol-taldearekin alderatuz, baita monozito askeen proteina erakartzaile-1en maila handiagoak ere $(p<0.0001)$ (7). Txerrietan, beste aldetik, 8 hileko ikerketa batean, proteina ugariko taldeak giltzurrun handiagoak izan zituen, ikerketa amaierarako glomeruluen bolumena \% 60-70 handitu zelarik. Handitutako giltzurrun horiek kalte histologikoa zuten, \% 55 fibrosi gehiago eta \% 30 glomeruluesklerosi gehiagorekin (2. irudia). Giltzurruneko monozito askeen proteina erakartzailea-1 (inflamazioaren markatzailea) maila handiagoan agertu zen, \% 22 handiagoan konkretuki. Aurkikuntza hauek iradokitzen dute, proteina ugariko dietek epe luzera giltzurrunen osasuna konprometitu dezaketela (8). Aipatu beharra dago, aitzitik, arratoiak azkarrago zahartzen direla gizakiak baino. Emaitzek adierazten dutena gizakiengan gerta daitekeen ala ez, ez dakigu gaur egun. 
2. irudia Arratoien glomeruluen irudiak (a) proteina normalekiko dietarekin, (b) proteina ugariko dietarekin 4. hilabetean, Schiff azido periodikoarekin fixatua eta 20x handipenean. Gezi bakoitzak glomerulu bakarra adierazten du. Glomeruluak (c) NP dietarekin eta (d) HP dietarekin 17 hilabeteren ondoren, Sirius girruarekin fixatua eta 40x handipenean (7). Iturria: Wakefield AP House JD, Ogborn MR, Weiler HA, Aukema HM. A diet with 35\% of energy from protein leads to kidney damage in female Sprague-Dawley rats. Br J Nutr. 2011; 106(5):65663.
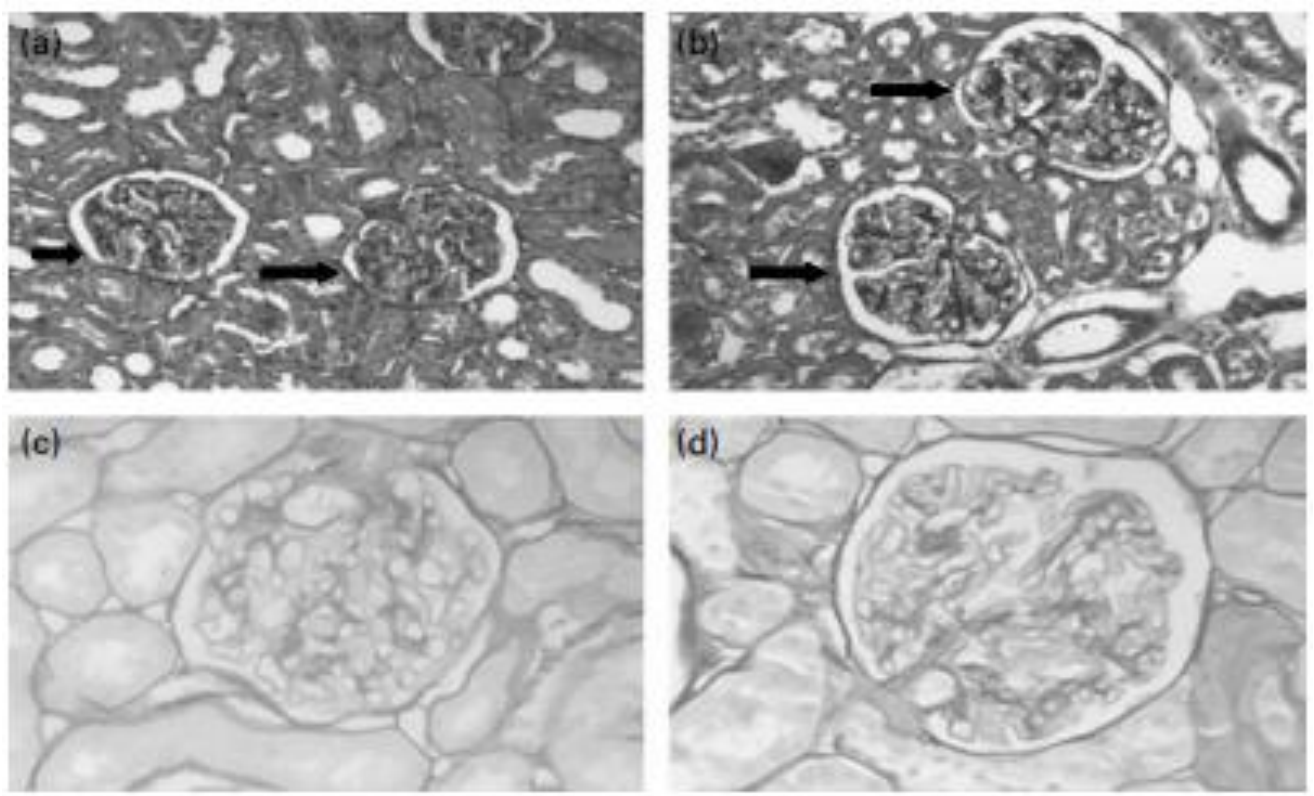

Beha dezagun giltzurrunaren lana: kontzentraturiko gernuan, urearen iraizketa normala ureairagazketa altuarekin baino ezin da mantendu. Hau ureako plasma-kontzentrazioa handituta edota GFR (glomerulu iragazketa tasa) handituz lor daiteke. Fenomeno hau behatua izan daiteke arratoi komunetan ur ekarpen/basopresina ardatzean normaltasunaren barnean dauden aldaketa kronikoak pairatzen dituztenean. Egoera oso antzekoa ematen da proteina ekarpenaren aldaketak ematen direnean. Bi kasuetan urea gehiago filtratu behar da, gehiago iraitzi behar delako, edo irazpenaren efizientzia jaitsi delako. Bi kasuetan antzerako mekanismoa proposatu da berauei azalpena emateko. Laburbilduz, ikerketok erakusten dute basopresinaren eragina GFR handipenaren eragile dela. GFR handipen honek urea plasmatikoaren kontzentrazioaren igoera ekiditen du, onuragarria izan daitekeena bere aldetik. Edozelan ere, hiperfiltrazio honek eragin mingarriak izan ditzake giltzurrun gaixoetan (9).

\subsection{Proteinen ekarpena egoera patologikoan}

Azken etapan dagoen giltzurrun gaixotasuna (ESKD) zuten paziente ez diabetikoek parte hartutako ikerketan, 3 talde desberdindu ziren: oso proteina gutxiko dieta (VLP), 0,3-0,4 g/kg/egun; proteina baxuak (LP) 0,5-0,6g/kg/egun eta proteina normalak (>0,8 g/ $\mathrm{kg} /$ egun). Proteina gutxiko (LP) dietak ez zuen dieta normalarekiko (NP) ia desberdintasunik erakutsi. Ez dago argi LP dietak eGFRan duen inpaktua NP dietarekin alderatuz. ESKD-dun horietan ez zen aurkitu heriotzan aldaketarik bi dietak alderatutakoan; baina LP dietak ESKDra helduko diren pazienteen kopurua murriz lezake. Berrikuspenak ondorioztatu zuen LP dietek ESKDra aurrera egingo duten 4-5 estadioko GGK duten 
paziente kopurua gutxitu lezaketela. Oso proteina gutxiko dietek, ordea, ez dute pronostikoa hobetzen NPrekin alderatuta (10)(3. taula).

3. taula Cl: konfiantza tartea; RR: arrisku erlatiboa; ESKD: amaierako etapako giltzurrun gaixotasuna; GFR: glomerulu iraizketa- tasa; SMD: estandarizatutako batez besteko aldea (10). Iturria: Hahn D, Hodson EM, Fouque D. Low protein diets for non-diabetic adults with chronic kidney disease. Cochrane Database Syst Rev. 2018 Urr 4;10:CD001892

\begin{tabular}{|c|c|c|c|c|c|}
\hline \multirow[t]{2}{*}{ Outcomes } & \multicolumn{2}{|c|}{ Anticipated absolute effects ${ }^{*}(95 \% \mathrm{Cl})$} & \multirow{2}{*}{$\begin{array}{l}\text { Relative } \\
\text { effect } \\
(95 \% \mathrm{Cl})\end{array}$} & \multirow{2}{*}{$\begin{array}{l}\text { No. of } \\
\text { participants } \\
\text { (studies) }\end{array}$} & \multirow{2}{*}{$\begin{array}{l}\text { Certainty of the } \\
\text { evidence } \\
\text { (GRADE) }\end{array}$} \\
\hline & Risk with normal protein diet & Risk with low protein diet & & & \\
\hline $\begin{array}{l}\text { Death (all } \\
\text { causes) }\end{array}$ & 55 per 1,000 & $\begin{array}{l}42 \text { per } 1,000 \\
(28 \text { to } 65)\end{array}$ & $\begin{array}{l}\text { RR } 0.77 \\
(0.51 \text { to } \\
1.18)\end{array}$ & $1680(5)$ & $\begin{array}{l}\oplus \oplus \oplus \ominus \\
\text { MODERATE }^{1}\end{array}$ \\
\hline ESKD & 144 per 1,000 & $\begin{array}{l}151 \text { per } 1,000 \\
(105 \text { to } 220)\end{array}$ & $\begin{array}{l}\text { RR } 1.05 \\
(0.73 \text { to } \\
1.53)\end{array}$ & $1814(6)$ & $\begin{array}{l}\oplus \oplus \Theta \Theta \\
\mathrm{LOW}^{12}\end{array}$ \\
\hline $\begin{array}{l}\text { End or } \\
\text { change in } \\
\text { GFR }\end{array}$ & \multicolumn{2}{|c|}{$\begin{array}{l}\text { The SMD for end or change in GFR was } 0.18 \text { lower ( } 0.75 \text { lower to } 0.38 \text { higher) with low } \\
\text { protein diet compared to normal protein diet }\end{array}$} & - & $1680(8)$ & $\begin{array}{l}\oplus \Theta \Theta \Theta \\
\text { VERY LOW }\end{array}$ \\
\hline
\end{tabular}

*The risk in the intervention group (and its $95 \%$ confidence interval) is based on the assumed risk in the comparison group and the relative effect of the intervention (and its $95 \% \mathrm{Cl}$ ).

Badira proteina ugariko dietak giltzurrun-funtzioari eragin diezazkiokeen bestelako kalteak ere: organoaren masa handiagoa eta histologian behagarria den ehunen kaltea. Animalietan egindako saiakuntzetatik atera daitezkeen ondorioak mugatuak izanda ere, proteina ugariko dieten bigarren mailako efektu fisiopatologikoak gizakiengan ere ager litezke. GGK ezarrita duten pazienteetan bederen, dietaren guztizko proteinaren ingestioa murriztuz gero (mugatu gabeko proteina ekarpenarekiko), edozein kausarengatiko heriotzek \% 32 egiten dute behera. Hamazazpi kohortetan batutako datuez baliatuta, proteina ugariko/ karbohidrato gutxiko dietak kausa guztiengatiko heriotza-tasa handitzearekin lotuta daudela iradoki da (10).

\subsection{Proteinen ingestioa aktibitate fisikorik gabeko norbanako osasuntsuengan zein gaixotasun gabeko patologia aurreko egoeran}

Hogeita hamar ikerketa (1-24 hilabeteko luzerakoak) eta guztira 2.160 subjektu aztertu dituen (osasuntsu, obeso, zein Diabetes Mellitus 2 zutenak) 2014ko meta-analisi batean ondorioztatu zen, proteina ugariko dietak glomerulu iragazketa-tasa nabarmenago handitzen zuela (MD: 7,18 $\mathrm{ml} / \mathrm{min} / 1,73 \mathrm{m2}, 95 \% \mathrm{Cl}$ 4,45-9,91, $\mathrm{p}<0.001$ ), serumeko urean [MD: 1,75 mmol/l, 95\% Cl 1,13-2,37, $\mathrm{p}$ $<0,001$ ] eta gernuko kaltzioaren iraizketan (MD: 25,43 mg/24h, 95\% Cl 13,62-37,24, p <0,001) LP/NP protokoloarekin alderatuta (11)( 4. taula). Aurkikuntza hau gehienbat proteina iturria animalia zelako azal liteke, jatorri hauetako proteinek duten purina kantitate handiek duten efektuak direla eta. Purina kantitate handiek bihotz-hodietako arriskua handitu dezakete, baita hezueriaren arriskua ere. 
4. taula. \% $95 \mathrm{Cl}$-rekin adierazitako batez bestekoen aldeak (MD) HP vs NP/LP dieten arteko efektuen emaitzak alderatzeko (11). Iturria: Schwingshackl L, Hoffmann G. Comparison of high vs. normal/low protein diets on renal function in subjects without chronic kidney disease: a systematic review and meta-analysis. PLoS One. 2014; 22;9(5):e97656.

\begin{tabular}{lllllll}
\hline Outcomes & $\begin{array}{l}\text { No. of } \\
\text { Studies }\end{array}$ & $\begin{array}{l}\text { Sample } \\
\text { size }\end{array}$ & MD & $95 \% \mathrm{CI}$ & $\begin{array}{l}\mathrm{p}- \\
\text { values }\end{array}$ & $\begin{array}{l}\text { Inconsistency } \\
\mathrm{I}^{2}\end{array}$ \\
\hline GFR $\left(\mathrm{m} / \mathrm{min} / 1.73 \mathrm{~m}^{2}\right)$ & 21 & 1599 & 7.18 & {$[4.45,9.91]$} & $<0.001$ & $52 \%$ \\
Creatinine $(\mu \mathrm{mol} / \mathrm{l})$ & 22 & 1764 & -1.42 & {$[-3.50,0.65]$} & 0.18 & $57 \%$ \\
Urea $(\mathrm{mmol} / \mathrm{l})$ & 13 & 910 & 1.75 & {$[1.13,2.37]$} & $<0.001$ & $88 \%$ \\
Uric acid $(\mu \mathrm{mol} / \mathrm{l})$ & 8 & 295 & 0.18 & {$[-0.08,0.44]$} & 0.17 & $3 \%$ \\
Urinary $\mathrm{pH}$ & 7 & 210 & -0.39 & {$[-0.82,0.03]$} & 0.07 & $95 \%$ \\
Urinary Albumin/Protein $(\mathrm{mg} / 24 \mathrm{~h})$ & 11 & 783 & 0.50 & {$[-2.83,3.82]$} & 0.77 & $63 \%$ \\
Urinary calcium excretion & 10 & 708 & 25.43 & {$[13.62$,} & $<0.001$ & $90 \%$ \\
(mg $/ 24 \mathrm{~h})$ & & & & $37.24]$ & & \\
\hline
\end{tabular}

Proteina ugariko dietak GIT serumeko urea, gernuko kaltzio-iragazketa eta serumeko azido urikoarekin lotu ziren. Obesoen artean GGKaren arrisku handia kontuan hartuta, pisua galtzeko proteina ugariko dietak (batez ere animalia jatorriko proteinak) gomendatzen dituzten programak kontu handiz maneiatu beharko lirateke (11). Meta-analisi honen jomuga GGKrik ez duten pazienteengan proteina kopuru normaleko eta handiko dietek duten eragina izan zen. Aurkikuntza nagusia proteina ugariko dieta zuten pazienteek GIT,serumeko urea, gernuko kaltzio-iragazketa eta serumeko azido urikoan kontzentrazioen igoera azaldu zutela da.

Saiakuntza kliniko gurutzatu batean proteina ugariko dieta eta proteina normaleko dieta alderatu ziren, zeinetan proteina kopurua $2,4 \mathrm{~g} / \mathrm{kg} / 24 \mathrm{~h}$ eta $1,2 \mathrm{~g} / \mathrm{kg} / 24 \mathrm{~h}$ ziren, hurrenez hurren. Hogeita lau gazte osasuntsuk zazpi egunez hartu zuten dieta bakoitza, eta hainbat parametro neurtu zitzaien zazpigarren egunean. Glomerulu-iragazketaren tasa (NP: 125 +/- $5 \mathrm{ml} / \mathrm{min}$; HP: $141+/-8 \mathrm{~mL} / \mathrm{min}$; P< 0,001) (5. taula) eta iragazketa frakzioa* (NP: $23+/-5 \%$; HP: $28+/-5 \%$; $P<0,05$ ) nabarmen handitu zen proteina ugariko dietarekin (12). Bestalde, odoleko urea nitrogenatua, serumeko azido urikoa, glukagoia, natriuresia, albuminuria eta urearen iragazpena ere era esanguratsuan handitu ziren proteina ugariko taldean (6. taula). Ikerketak ondorioztatu zuen denbora motzean mantendutako proteina ugariko dietak giltzurruneko hemodinamika eta giltzurruneko azido urikoaren, sodioaren eta albuminaren iragazpenak aldatzen dituela. Era honetan, adi egon behar dugu proteina ugariko dietekin eta berauen efektuekin. Eta aipatutako aldaketek luzetara giltzurrunean kaltea ekar dezaketela ere ondorioztatu zen, baina ezin daiteke ahaztu ikerketak lagin txikia zuela eta denboratarte motzean egin zela.

*Glomerulutik pasako den plasma kantitatean zenbateko likido proportzioa pasatzen den gernura. 
5. taula Glomerulu-iragazketaren tasa, giltzurruneko plasma fluxua (RPF) eta kalkulatutako giltzurruneko hodien erresistentzia (RVR) 24 gizonengan, 2 dieten arabera. 1, bolumen guztiak batez bestekoak dira \pm desbiderazio estandarra (SD). 2, 0 taldeak lehendabizi NP dieta burutu eta gero HP egin zuen. 3, 1 taldeak lehendabizi HP dieta eta ostean NP dieta egin zuen (12). Iturria: Frank $\mathrm{H}$ et al. Effect of short-term high-protein compared with normal-protein diets on renal hemodynamics and associated variables in healthy young men. Am J Clin Nutr. 2009; 90(6):1509-1516

\begin{tabular}{lccccc}
\hline & Group 0: NP $\rightarrow \mathrm{HP}^{2}$ & \multicolumn{2}{c}{ Group 1: $\mathrm{HP} \rightarrow \mathrm{NP}^{3}$} \\
\hline & $n$ & Mean \pm SD & $n$ & Mean \pm SD \\
\hline GFR under NP $(\mathrm{mL} / \mathrm{min})$ & 13 & $125.7 \pm 4.70$ & 11 & $124.1 \pm 5.08$ \\
\hline GFR under $\mathrm{HP}(\mathrm{mL} / \mathrm{min})$ & 13 & $141.3 \pm 7.82$ & 11 & $139.6 \pm 8.20$ \\
\hline RPF under NP $(\mathrm{mL} / \mathrm{min})$ & 13 & $506.5 \pm 15.54$ & 11 & $507.5 \pm 19.36$ \\
\hline RPF under $\mathrm{HP}(\mathrm{mL} / \mathrm{min})$ & 13 & $501.2 \pm 25.45$ & 11 & $490.5 \pm 25.43$ \\
\hline RVR under NP $\left(\mathrm{mm} \mathrm{Hg} \cdot \mathrm{mL}^{-1} \cdot \mathrm{min}^{-1}\right)$ & 13 & $99.0 \pm 7.97$ & 11 & $97.5 \pm 9.02$ \\
\hline RVR under $\mathrm{HP}\left(\mathrm{mm} \mathrm{Hg} \cdot \mathrm{mL}^{-1} \cdot \mathrm{min}^{-1}\right)$ & 13 & $93.9 \pm 5.51$ & 11 & $94.3 \pm 7.34$ \\
\hline
\end{tabular}

6. taula. Proteina ugariko (HP) eta proteina normaleko (NP) dietak burutu zituzten gizonezko osasuntsuen gernuko aldaera kimikoak (12). Iturria: Frank $\mathrm{H}$ et al. Effect of short-term highprotein compared with normal-protein diets on renal hemodynamics and associated variables in healthy young men. Am J Clin Nutr. 2009; 90(6):1509-1516.

\begin{tabular}{llll}
\hline & NP diet & HP diet & P value $^{2}$ \\
\hline Urinary albumin $(\mathrm{mg} / 24 \mathrm{~h})$ & $8.7 \pm 7$ & $18.3 \pm 7$ & $<0.05$ \\
\hline Urine pH & $6.45 \pm 0.39$ & $5.79 \pm 0.47$ & $<0.05$ \\
\hline Specific gravity & $1020 \pm 10$ & $1020 \pm 5$ & NS \\
\hline Sodium excretion $(\mathrm{mmol} / \mathrm{d})$ & $173.4 \pm 64$ & $215.6 \pm 53$ & $<0.05$ \\
\hline Urea nitrogen excretion $(\mathrm{mg} / \mathrm{d})$ & $9094 \pm 1599$ & $13915 \pm 2275$ & $<0.01$ \\
\hline Creatinine excretion $(\mathrm{mg} / \mathrm{d})$ & $1796 \pm 292$ & $1989 \pm 381$ & 0.12
\end{tabular}

Hala ere, beste era bateko jarrera duten ikerketak ere agertu dira. GGK garatuta ez zuten pertsona obesoetan 3 urteko saiakuntza kliniko aleatorizatua egin zen, guztira 310 parte hartzaile batu zituena. Egindako dietak hasierako gorputz-masaren $\geq \% 8$ galtzea zuen helburu, mantentze fase batez jarraitua. LP (proteina baxua) taldeak $1,0 \mathrm{~g} / \mathrm{kg} /$ egun proteina kontsumituko zituen; MP (bitarteko proteina kopurua) dieta 1,3 g/kg/egun -\% 15 proteina, \% 55 karbohidratoak eta bitarteko indize gluzemikoa ( $\mathrm{Gl}, \geq 56$ )- eta HP (proteina kopuru handia) dietak 1,6g/kg/egun $-\% 25$ proteina, \% 45 
karbohidrato eta indize gluzemiko txikiagoa $(\leq 50)$ - alderatu ziren. Bi dietetan gantzen ingestioa \% 30ekoa zen. Era berean, ariketa fisikoa egiterakoan bi talde banatu ziren: batak intentsitate handiko ariketa fisikoa 75 minutu/aste eta besteak bitarteko intentsitatea zuen ariketa egin zuen 150 $\mathrm{min} /$ aste. Bi programek $>4.200 \mathrm{KJ} /$ asteko $(1.000 \mathrm{Kcal}$ inguru) gastua bilatu zuten. Giltzurrunaren funtzioa 24h-ko gernuan kreatininaren argitzea neurtuz aztertu zen, estimatutako glomerulu iragazketa (eGIT) CKD-EPI formula erabiliz kalkulatu zelarik. Kreatininaren argitzea, gernuko kreatinina, eta serumeko urearen aldaketak, urearen iragazpenarekin batera kalkulatuta, estimatutako proteinen ingestioarein zuzenean lotu ziren $(p<0,0001)$ (7. taula). Saiakuntza klinikoarekin ondorioztatu da ez dagoela proteinen ingestioa handitzeak (oinarrizko proteinen ingestioa edozein delarik ere) giltzurrunetan kalterik sor dezakeen iritziari eusteko oinarririk. Saiakuntzaren aurkikuntza nagusia da proteinen ingestio handiagoa ( $>1,6 \mathrm{~g} / \mathrm{kg} / \mathrm{egun})$ ez zegoela giltzurrunaren funtzio galerarekin erlazionatuta, pisu galerarentzako eta osteko mantenurako urte bateko interbentzioaren ostean, diabetes aurrekoa aurkezten zuten helduetan. Norbanako osasuntsuengan, kalorien ingestioan \% 30era arteko proteinen ingestioak ez du erakutsi giltzurrunean eragin kaltegarririk (13).

7. taula. Estimatutako proteinen ingestioren (urearen iraizketaren aldaketen bidez kalkulatua) eta giltzurrunaren funtzioaren aldaketa urte bateko epean (13). Iturria: Møller G et al. Higher Protein Intake Is Not Associated with Decreased Kidney Function in Pre-Diabetic Older Adults Following a One-Year Intervention-A Preview Sub-Study. Nutrients. 2018; 10(1).

\begin{tabular}{ccccccc}
\hline \multicolumn{7}{c}{$\Delta$ Estimated Protein Intake $(\mathrm{g} / \mathrm{kg} /$ Day) Calculated from the Urea Excretion } \\
\hline Variable & $n$ & $\begin{array}{c}\text { Unadjusted } \\
(\beta \pm \mathrm{SE})\end{array}$ & $p$-Value & $n$ & $\begin{array}{c}\text { Adjusted } \\
(\beta \pm \mathrm{SE})\end{array}$ & $p$-Value \\
\hline$\Delta$ Creatinine clearance $(\mathrm{mL} / \mathrm{min})$ & 29.4 & $75.86 \pm 4.31$ & $<0.0001$ & 219 & $72.86 \pm 4.94$ & $<0.0001$ \\
$\Delta$ eGFR $\left(\mathrm{mL} / \mathrm{min} / 1.73 \mathrm{~m}^{2}\right)$ & 309 & $2.06 \pm 1.32$ & 0.118 & 230 & $3.42 \pm 1.56$ & 0.03 \\
$\Delta$ U-Albumin/U-Creatinine ratio (ACR) & 309 & $-1.12 \pm 4.47$ & 0.09 & 230 & $0.53 \pm 5.24$ & 0.920 \\
$\Delta$ Urea/Creatinine Ratio (UCR) & 309 & $9.64 \pm 2.22$ & $<0.0001$ & 230 & $13.53 \pm 2.60$ & $<0.0001$ \\
$\Delta$ S-Creatinine (umol/L) & 309 & $-2.14 \pm 1.31$ & 0.104 & 230 & $-3.59 \pm 1.55$ & 0.02 \\
$\Delta$ S-Urea (mmol/L) & 309 & $0.62 \pm 0.16$ & $<0.001$ & 230 & $0.84 \pm 0.19$ & $<0.0001$ \\
\hline
\end{tabular}

All values are beta \pm SE. Statistical differences between changes is based on analysis of covariance. Beta is the slope coefficient of outcome measures, per 1 unit change in estimated protein intake $(\mathrm{g} / \mathrm{kg} /$ day) from urea excretion Model Adjusted for age, gender, physical activity (moderate and vigorous), and study site (the University of Copenhagen, the University of Helsinki, the University of Auckland, the University of Navarra, and the University of Nottingham). Abbreviations: eGFR: estimated glomerular filtration rate; $\mathrm{S}$-Creatinine: serum creatinine; $\mathrm{S}$-Urea: serum urea.

2018an argitaratutako meta-analisi batean 2144 laburpen berrikusi ziren, horietatik testu osoko 40 berrikuspen egiteko (14). Horietatik 28 ikertuak izan ziren eta 1358 parte hartzaileren datuak batu zituen. Bi taldetan banaturik HP taldeak $>1,5 \mathrm{~g} / \mathrm{kg} /$ egun edo energiaren $\%>20$ edo $>100 \mathrm{~g} /$ egun hartuko zituen; eta NLP taldeak, HP taldearekin alderatuta \%5 gutxiago, ikerketan sartzeko. $>4$ eguneko iraupena zuten ausazko saiakuntza klinikoak hartu ziren ikertzeko. Ikerketan onartua izateko irizpideen artean pertsona osasuntsua, obesoa, HTA eta 2 motako DM zutenak zeuden. Ikerketatik kanpo geratu ziren 1 motako DM, GGK, proteinuria edo giltzurrun-kaltea adieraz zezaketen edozein markatzaile zuten pertsonak.

Emaitzak alderatzerakoan, GGKrik ez zuten norbanakoetan HP $(1.81+0.60 \mathrm{~g} / \mathrm{kg} / \mathrm{egun})$ eta NLP $(0,93+$ $0,51 \mathrm{~g} / \mathrm{kg} /$ egun) dietak alderatu ziren. Jatorriz, Brenner et al.-ek proposatu zuten glomeruluaren hiperfiltrazioaren eta giltzurruneko kaltearen arteko harremana, eta horretan GIT handipena nefronen galera konpentsatzeko erantzuna zela iradoki zen. Ebidentziak aurkezten duen informazioaren aldarrien artean, proposamenetako bat da gizakiengan, proteinen elikatzearen edo beste estimulu batzuen (haurdunaldia, nefrektomia...) aurreko hiperfiltrazio glomerularra giltzurrun osoan ematen dela, giltzurruneko odol fluxua handitzearen ondorioz. Meta-analisiko azpianalisien 
artean proteinen osteko (post) dosi menpeko efektua behatu zen proteinen eta GFRaren artean. Beste alde batetik, nahiz eta aipatutako proteinen dosi-erantzun efektua post GFR aldaketan esanguratsua izan, ez zen harreman esanguratsurik aurkitu proteina dosi eta GFR aldaketaren artean interbentzioa egin ostean (14) (3. Irudia). Honek esan lezake, nahiz eta proteinekin erlazionatutako GFR handipena egon, honen dosi handipenek GFR aldaketekin loturarik erakutsi ez dutenez, proteinei ezin zaiela efektu hau egotzi.

3. irudia. A: Proteinen ingestioaren eta ondorengo eGITren arteko dosi-erantzunetako efektuaren arteko erregresio lineala $(r=0,332, p=0,03)$. B: GFR aldaketa ( $\triangle G F R)$ interbentzioari erantzuten pertsona osasuntsuetan $(r=0,184, p=0,33)$. GFR eta $\triangle G F R$ $\mathrm{ml} / \mathrm{min}$ edo $\mathrm{ml} / \mathrm{min} / 1,73 \mathrm{~m} 2$ eran irudikatu da, ikerketaren arabera argiketa edo eGFR neurketa eman delako. BW: gorputz-masa; eGFR: estimatutako glomerulu iragazketa-tasa; GFR: glomerulu iragazketa-tasa (14). Iturria: Devries MC et al. Changes in Kidney Function Do Not Differ between Healthy Adults Consuming Higher-Compared with Lower-or NormalProtein Diets: A Systematic Review and Meta-Analysis. J Nutr. 2018; 148(11):1760-1775.

A

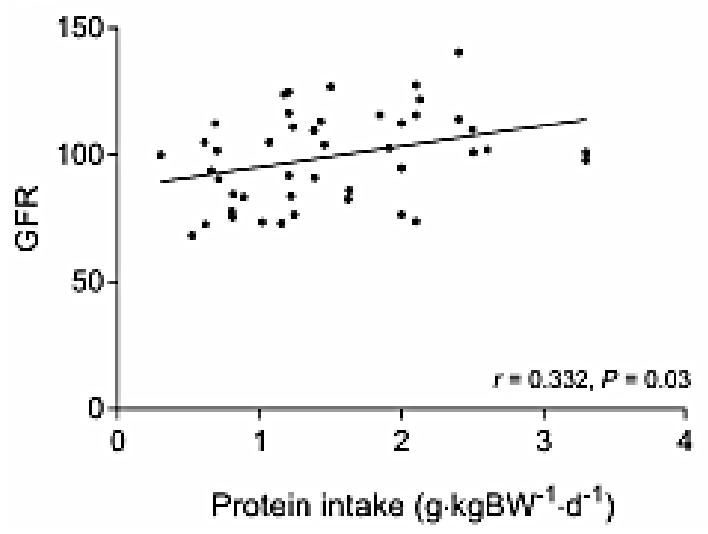

B

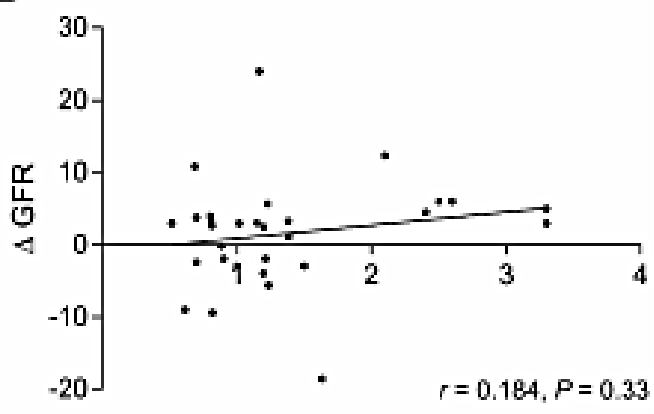

Protein intake $\left(g \cdot \mathrm{kgBW}^{-1} \cdot \mathrm{d}^{-1}\right)$

\subsection{Proteinek gernuan eragin ditzaketen aldaketak}

Ikerketa batean 74 atletaren gernu-lagina aztertu zen proteina kantitatea neurtzeko asmoz, gernuak eman dezakeen informazioa baliatuta. Lagin horietako batzuk baztertuak izan ziren proteinuria sortzen zuen baldintzaren bat izatearren, edo lagina alda zezakeen baldintzaren bat aurkezteagatik. Aukeratutakoen artean sortu zen talde esperimentala, zeinak proteina osagarrien (era artifizialean sintetizaturiko proteinak) kontsumoaren aurrekariak zituzten gizabanakoak batuko zituen, kontrol taldeak proteina osagarrien kontsumorik hartzen ez zuten banakoak batuko zituelarik. Proteina osagarriek giltzurrunen funtzioa kaltetzen ez dutela ondorioztatu zen, eta mikroproteinurian (giltzurrunen kaltearen susmarazi) ez zuela aldaketa esanguratsurik eragin ( $p=0.4564$ ), emaitzei behatuta. Dena dela, etorkizunean proteina osagarriak giltzurrunaren funtzioa alda dezaketen egoera edo patologiak dituzten taldeetan aztertu beharko litzateke (15).

\subsection{Proteinek kirolarietan eragindako ondorioak}

Hainbat egoeratan gertatzen da proteinen kontsumoa. Batetik pisua galtzeko, eta oso ohikoa den beste eremu batean, gimnasioan aritzen diren pertsonek muskulu-masa handitzeko. Honen harira, 49 ikerketa eta guztira 1.864 norbanako aztertu zituen meta-analisi batek (16), proteinen ingestioa handitzeak zekartzan efektuak neurtzen zituztenak. Erresistentziarako Entrenamendua (EE) eta proteina osagarriak (sintetikoak, gehienetan esnearen eratorriak, hauts formatuan salduak, irabiakiak edo bestelakoak prestatzeko) konbinatzen zituzten ausazko kontrolatutako saiakuntzak hartu ziren 
kontuan. EEren irizpideak betetzeko, $>6$ asteko iraupena izan behar zuen eta astean 2 entrenamendu baino gehiago egin behar zuten parte hartzaileek. Horietan bi talde banatu ziren; batak proteina osagarriak hartuko zituen, beste agente hipertrofia sortzailerik hartu gabe. Honela, entrenamenduek 6-52 astez iraun zuten ( $13 \pm 8$ aste) eta entrenamenduek 2-5 egun/aste izan ziren ( $3 \pm 1$ egun/aste). Entrenamenduak 1-14 ariketa ( $7 \pm 3$ ariketa/sesio), 1-12 serie/ariketa ( $4 \pm 2$ serie/ariketa) eta 3-25 errepikapen/serie $(9 \pm 4$ errepikapen/serie) izan ziren. Proteina osagarriak hartzen zituen taldeak proteinen ingestioa handitu zuen $(23 \pm 14 \mathrm{~g} /$ egun; $p=0,004)$, kontrol taldean aldaketa esanguratsurik agertu ez zelarik (1+14 g/egun; $p=0.83)$. Hogeita hiru saiakuntzatan batutako datuetan, kalorien kontsumoa (kcal/egun) ez zen aldatu luzatutako EErekin eta proteina osagarriekin, ezta aldaketa esanguratsurik aurkitu proteinak hartzen zituzten eta kontrol taldekoen artean ( $\Delta$ proteina hartzaileen taldea: 50+293 kcal/egun, $\Delta$ kontrol taldea: 70+231 kcal/egun, $p=0,71$ ).

Proteina osagarriek EEk eragindako 1RM (errepikapen maximoa) eta GGM (gantzik gabeko masa) irabazietan hobekuntza zekarrela izan zen ikerketako aurkipen nagusia. GGMn aldaketak nabariagoak izan ziren entrenatutako norbanakoetan $(0,75 \mathrm{~kg}(0,09,1,40), p=0,03)$ eta norbanakoa zenbat eta adintsuagoa izan, orduan eta efektu txikiagoa lortuko zuen $(-0,01 \mathrm{~kg}(-0,02,-0,00), \mathrm{p}=0,002)$. Proteina osagarritasunak 1,62 g/kg/egun-etik gora, ez zituen GGM irabaziak era esanguratsuan handitu (4. Irudia).

4. Irudia. Proteinen ingestio totalaren $(\mathrm{g} / \mathrm{kg} / \mathrm{egun})$ eta gantzik gabeko masaren aldaketaren $(\triangle F F M)$ segmentuko erregresio lineala, $X$ izpien absortziometria bidez neurtua. Zirkulu bakoitzak ikerketa bateko talde bat irudikatzen du. Lerro eteneko geziak eten puntua adierazten du: $1.62 \mathrm{~g} / \mathrm{kg} /$ egunm $\mathrm{p}=0,079$. Lerro jarraituko geziak \% $95 \mathrm{Cl}(1,03-2,20)$ adierazten du (16). Iturria: Morton RW et al. A systematic review, meta-analysis and metaregression of the effect of protein supplementation on resistance training-induced gains in muscle mass and strength in healthy adults. Br J Sports Med. 2018; 52(6):376-384.

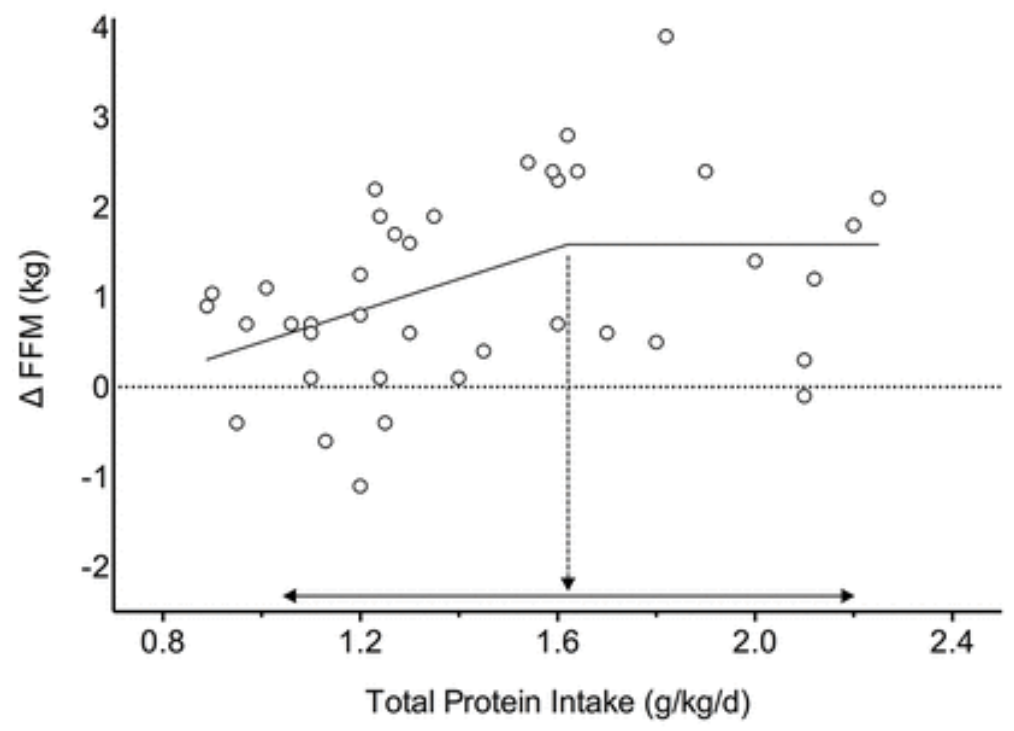

Honela, proteina osagarriei egotzi diezazkiokeen onurak ohiko proteinarekin lor daitezkeela esan liteke, eta osagarriek helburua lortzen lagunduko gaituztela. Bestalde, entrenatutako banakoek masa-irabazi nabariagoak dituzte, berauek duten proteina aprobetxatzeko ahalmena handiagoa delako, ez indarrean osagarriak hartu dituztelako.

Proteinen kontsumoa, beraz, erabilgarria eta garrantzitsua da EE egiten dutenetan. Literaturak dio norbanako aktiboetan 1,.4-2,2 $\mathrm{g} / \mathrm{kg} /$ egun-eko kontsumoa beharrezkoa dela. Modu honetan, saiakuntza batean proteina oso ugariko dietek $(4,4 \mathrm{~g} / \mathrm{kg} / \mathrm{egun})$ entrenatutako gizon zein emakumeen gorputzean zuen eragina ikertu zen (17). Entrenatutako pertsonekin egindako 8 asteko saiakuntzaren ostean, 20 parte hartzaile HP taldean eta 10 kontrol taldean, ondorioztatu zen HP (proteina ugari) dieta hiperkalorikoek ez dutela gantz-masa handitze, baizik eta GGM (gantzik gabeko masa). Ez zen bigarren mailako efektuak (gibel- edo giltzurrun-mailan) neurtzeko odol analitikarik egin. Nahiz eta 
muskulu-masa handitu (helburuen arabera onuragarria da), ez da giltzurruneko edo gibeleko kalterik aztertu, eta horrek beraz ikerketari balioa kentzen dio berrikuspen honetan ikertu nahi den puntuaren inguruan, ez baitzelako giltzurruneko kalterik neurtu.

Aurretik ikusita geneukan 1,62 g/kg/egun proteina kantitate baino altuagoek ez zekartzatela GGM masa handipen esanguratsurik, entrenatu gabeko norbanakoetan bederen. Literaturak ordea, aipatzen du gure helburuak betetzerako orduan $2-2,5 \mathrm{~g} / \mathrm{kg} / \mathrm{egun}$ ere hartzea dagoela. Beste kasu batzuetan ere kantitate altuagoak bilatu dira. Kasu honetan EEan sartuta zeuden 12 gizon osasuntsuk boluntario aurkeztu zuten bere burua 16 astez. Hauetan, 8 astez HP dieta $(3,3+0,8 \mathrm{~g} / \mathrm{kg} / \mathrm{egun})$ ezarri zitzaion erdiari, normala $(2,6+0,8 \mathrm{~g} / \mathrm{kg} /$ egun) beste erdiari, eta beste 8 astez taldeak aldatu ziren, saiakuntza gurutzatua sortzeko. Biei antolatutako EE astuna egokitu zitzaien. HP taldeak, kontrol taldeak baino esanguratsuki kaloria gehiago kontsumitu zituen $(p<0,05)(18)$, bi taldeen artean dietaren egituran alderik ez zegoelarik. Gorputz-konposaketan edo osasun-markatzaileetan ez zen aldaketa esanguratsurik aurkitu, ez talde batan ez bestean. Odol analisien bidez neurtuta (profil orokorra, giltzurrun-profila eta gibel-profila, lipidoen profila barne), ez zen bigarren mailako efekturik (adibidez odoleko lipidoetan, glukosan, giltzurrunetan gibelean eta abar) proteinen ingestioarekin lotura zutenik aurkitu. Saiakuntzari egotzitako ondorioak: entrenamendua nabarmen aldatzen ez duten entrenatutako gizonetan, proteina ugariko dieta kontsumituta $(2,6-3,3 \mathrm{~g} / \mathrm{kg} / \mathrm{egun}), 16$ asteren epean ez dago aldaketarik odoleko lipidoetan edota giltzurrun zein gibelen markatzaileetan. Aztertutako epean, ikusi da HP dietak eta EE astunarekin efektu positiboa dutela gorputzkonposaketan, baina osasunerako ondoriorik gabe. Esan beharra dago dieta normaleko taldean proteinen kontsumoak aski erraz gainditzen zuela (bikoiztu ere) MOEk gomendatzen duen kantitatea: $2,6 \mathrm{~g} / \mathrm{kg} /$ egun vs $1-1,2 \mathrm{~g} / \mathrm{kg} /$ egun.

\subsection{Eztabaida}

Berrikuspen honetan batu diren iturrietako ondorioak aztertuta, bi jarrera nagusi bereiz litezke: (i) proteina kontsumoarekin adi ibiltzeko mezua darabiltenak, honen gehiegizko ekarpenak epe luzean kalte egingo bailioke giltzurrunaren funtzioari; eta (ii) proteina kantitate handien kontsumoaren alde daudenak, honek giltzurrun osasuntsuetan kalterik sortzen ez omen duelako.

Proteinen gehiegizko kontsumoaren aurkako argudioen artean aintzat har daiteke aktibo ez diren gazteengan, nahiz eta osasuntsu egon, proteina gehiegi jateak eGITn gernuan eragiten dituzten aldaketak dira (12). Era berean, HP dietek GGK duten pertsonengan jazarpen esanguratsua sortzeko ahalmena daukatenez, ekidin beharko lirateke. Meta-analisi batean behatu zenez, HP dietak nabarmenago handitzen ditu GIT eta gernuko kaltzioaren iraizketan, LP/NP protokoloarekin alderatuta (11); meta-analisian ondorioztatu zen, beraz, proteina ugariko dietek giltzurrun-funtzioan aldaketak eragin zitzaketela eta epe luzera kalte potentziala ere. Beste ikerketa batean ikusi zen proteina anitzen ingestio glomerulu-hiperfiltrazioarekin eta hiperemiarekin lotuta dagoela, eta era berean GGKren progresioarekin, proteinuria handitzearekin; diuresiarekin, natriuresiarekin, kaliuresiarekin eta odol-presioaren aldaketekin, nefrolitiasia (giltzurruneko kalkuluak) pairatzeko arrisku handiagoarekin, eta hainbat aldaketa metabolikorekin (1). Animalietan, bereziki arratoietan (7) eta txerrietan (8), glomeruluen esklerosia gertatzen da proteina ugariko dieten eraginez, baina oraindik ez dakigu gizakiengan ere fenomeno hau gertatzen den.

Beste alde batetik, orain arteko ikerketetan pertsona osasuntsuengan proteinek kalterik ematen ez dutela iradoki da $(19,20)$.

Proteinak seguruak direla eta norbanako osasuntsuetan bigarren mailako ondoriorik ez dakartela eusten dutenek proteina kantitate oso handietan ( $3,3 \mathrm{~g} / \mathrm{kg} / \mathrm{egun}$ ) ere ez dagoela odoleko lipidoetan edota giltzurruneko zein gibeleko markatzaileetan aldaketarik (13) dute argudio. Proteinen iturria edozein delarik ere, natural zein sintetiko (proteina osagarriak), giltzurrunen funtzioa kaltetzen ez dutela ondorioztatu zen, eta mikroproteinurian (giltzurrunen kaltea susmarazten duena) ez zuela ondoriorik, emaitzei behatuta (15). Egoera potentzialki patologikoa (baina gaixotasun ezarririk gabe) 
duten pertsonetan ere ez da behatu giltzurrun kalterik HP dieta hartutakoan (13). Zenbait metaanalisi ere proteinen kontsumoaren alde agertu dira: proteinen kontsumoak GGM handitzen duela adierazten du, nahiz eta entrenatu gabeko pertsonek $1,62 \mathrm{~g} / \mathrm{kg} /$ egun-etik gora onura esanguratsurik ez erakutsi, ez baitute hartutako proteinak aprobetxatzeko horrenbesteko ahalmenik (16). Azkenik, joan den 2018ko azaroan argitaratutako meta-analisi batek pertsona osasuntsuak, obesoak, HTA eta 2 motako DM zutenak ikertu zituen. HP taldean kontsumoa $>1.5 \mathrm{~g} / \mathrm{kg} /$ egun izan zen. Nahiz eta proteinen dosi-erantzunetako efektua post GFR aldaketan esanguratsua izan, ez zen harreman esanguratsurik aurkitu proteina dosi eta GFR aldaketaren artean interbentzioa egin ostean (14).

Zoritxarrez, proteina ugariko dieten ulermen sakona mugatua da, historikoki dieta hauen onarpena txikia izan baita. Ez da gizakietan epe luzeko proteina ugariko ingestioaren ikerketa zorrotzik egin (ikerketa askok eta askok 8-12. astetan moztu izan dute saiakuntza, eta gehienez 6-12 hilabetean jotzen du muga), gehiengoa tarte motzean geratzen delarik, eta proteina ugariko dietek pertsona obesoetan daukaten efektuaren datuak oso eskasak direlako.

Edozein kasutan, nahiz eta norbanako osasuntsuengan proteina ugariko dietak egiterakoan giltzurrunekin zerikusi duten kontraindikaziorik ez egon, arrisku hipotetikoak berrikusi beharko lirateke pazientearekin, hau da, norbanakoari moldatu. Era berean, proteina ugariko dietek GGK duten pertsonetan jazarpen esanguratsua sortzeko potentziala daukatenez, egoera horretan ekidin egin beharko lirateke. Kontuan hartu beharko litzateke GGK isilpeko gaixotasuna denez gero (gogoratu 30 urtetik aurrera ,GIT 10ml/min inguru jaisten dela hamarkada bakoitzeko, eta populazioaren \%20tik gora duela GGK, hasierako estadioetan bada ere), pertsona orok plasmako kreatininaren neurketa eta proteinuriaren test arina egin beharko lukeela horrelako dietarik hasi aurretik.

Beraz, baliteke proteinen kontsumoa ez izatea giltzurrun-funtzioaren galeraren errudun, baina badakigu GGKren progresioan parte hartzen duela. Hau ikusita, planteatu beharra dago proteina ugariko dietak dituzten pertsonek ez ote duten oinarrian isilpeko gaixotasunen bat, GGKra bideratuta dagoena.

Proteinen kontsumoa babesteko edo baztertzeko jarrerak aztertu dira. Orain arte ikusitakoa laburtzeko, hurrengo taulan bildu dira eztabaidan alderatutako argudioak (8. taula).

\section{8. taula}

Proteina ugariko dieten AURKA
-Animalietan glomerulu-esklerosia eta
giltzurrunen fibrosia dakarte.
-Gehiegizko kontsumoak eGFRan eta gernuan
aldaketak sortzen ditu. Nahiz eta osasuntsu
egon, honek kalte potentziala dauka.

-Nefrolitiasia sor dezakete.

-Giltzurruneko Gaixotasun Kronikoaren progresioa eragiten dute, proteinuria handituz. Proteinen murrizpenak, bukaerako etapan dagoen giltzurruneko gaixotasuna (ESKD) duten pertsonen kopurua murriztu dezake.

-Ikerketek iraupen mugatua dute. Ez dakigu 5, 10 edo 15 urteren buruan pertsona osasuntsuetan dieta hauek kalterik eman dezaketen ala ez.

\section{Proteina ugariko dieten ALDE}

-Gizakietan, animalietan behatutako fenomenoak ematen diren ez dakigu.

-Pertsona osasuntsuetan 3,3 g/kg/egun arteko kontsumoak ez du kalterik erakutsi giltzurrun zein gibeleko markatzaileetan.

-Pertsona osasuntsuenagan proteinen kontsumoak (iturria edozein delarik ere) ez du proteinuria ekartzen duenik erakutsi.

-Ez dute Giltzurruneko Gaixotasunik sortzen, oinarrian giltzurrun kalterik ez badago (HTA, DM motako arrisku faktoreak izanda ere).

-Giltzurrun-funtzioa egokia izanda, eta dieta egokia (batez ere landare jatorriko proteinekin) kirolarekin konbinatuta, proteinek ez dute arriskurik. 


\section{Etxera eramateko hausnarketa}

- Proteina ugariko dietak kaloria kopuru handiko dieta baten barnean proportzio egokian, hau da, balio osoan altuak, baina kaloria guztien <\%25 izanda, ez dute zertan kaltegarriak izan.

- Proteina ugariko dietak, ariketa fisikoarekin bat datorren dieta baten barruan (eta EEan arituak direnen artean), ez dute zertan kaltegarriak izan. Nahiko erraza da EEan zein beste kiroletan biziki dabiltzanen artean $1,6 \mathrm{~g} / \mathrm{kg} / 24$ proteina kopurutik igotzea, kalorien beharra asetzeko.

- Kirola edo EE egiten hastean proteinen behar txikiagoak daude muskulu-masa txikiagoa izateagatik, eta beronen asimilazio txikiagoarengatik ere. Honek azal lezake zergatik aurkitu den $>1,62 \mathrm{~g} / \mathrm{kg} /$ egun ez duela aldaketa nabarmenik erakusten.

- Proteinen kopuru handiak eragiten duen hiperfiltrazioak ez du zertan patologikoa izan, baldin eta oinarrizko GGKrik ez badago (gogoratu beharra dago askotan isilpeko zergati bat dagoela, edo hainbat faktore batera). Proteinek bestalde oinarrian eta ezkutaturik zegoen gaixotasunaren progresioa eragingo lukete.

- Proteinek filtrazioan eragiten duten handipena egokitze fisiologikoarekin batera doan arren, izan liteke denbora luzez mantenduta handipen horrek giltzurrunei kalte egitea.

- GGKn, batez ere proteinuria dagoen kasuetan, ezin daiteke gomendatu proteina ugariko dieta egitea.

- Baliteke dietako proteinak asko murrizteak ez duela GGKren progresioa eteten, baina GGKren 4. eta 5. estadioetan dauden pazienteetan, amaierako estadiora heltzeko denbora luzatzen dela.

- Gizartean dagoen "ezkutuko" GGKren prebalentzia uste baino handiagoa dela jakinda, proteina ugariko dieta batean abiatu aurretik, dagozkien kontrolak egin beharko lirateke.

- Saiakuntzak epe motzekoak dira, eta ez da kalte histologikoa edo zeharkako markatzailerik bilatu. Honela, proteinen ingestioa noiz den gehiegizkoa eta noiz kalte ematen duten esatea oso lantsua eta lausoa bihurtzen da.

\section{Jakinarazpenak}

Autoreek adierazi egiten dute, argitalpen honek ez daukala inolako interes gatazkarik.

\section{Erreferentzia bibliografiak}

1. Friedman AN. High-protein diets: potential effects on the kidney in renal health and disease. Am J Kidney Dis. 2004; 44(6):950-62. Eskuragarri: https://www.ajkd.org/article/S0272-6386(04)01253-3/fulltext

2. Gaínza de los Ríos, J. Insuficiencia Renal Aguda. Hemen: Lorenzo V, López Gómez JM (Eds). Nefrología al Día [Internet]. Santander: Sociedad Española de Nefrología; c2018 [Eguneratuta: 2018-06-25; Kontsulta: 2019-02-11]. 21 or. Eskuragarri: http://www.revistanefrologia.com/esmonografias-nefrologia-dia-articulo-insuficiencia-renal-aguda-158 
3. Lorenzo V. Enfermedad Renal Crónica. Hemen: Lorenzo V, López Gómez JM (Eds). Nefrología al Día [Internet]. Santander: Sociedad Española de Nefrología; c2018 [Eguneratuta: 2018-0625; Kontsulta: 2019-02-11]. 29 or. http://nefrologiaaldia.org/es-articulo-enfermedad-renalcronica-136

4. Cheung KL, Lafayette RA. Renal physiology of pregnancy. Adv Chronic Kidney Dis. 2013; 20(3):209-14. Eskuragarri: https://www.ncbi.nlm.nih.gov/pmc/articles/PMC4089195/

5. Friedman AN, Yu Z, Juliar BE, Nguyen JT, Strother M, Quinney SK, Li L, Inman M, Gomez G, Shihabi Z, Moe $S$. Independent influence of dietary protein on markers of kidney function and disease in obesity. Kidney Int. 2010; 78(7):693-7. Eskuragarri: https://www.kidneyinternational.org/article/S0085-2538(15)54603-6/fulltext

6. Aluko EO, Nna VU, Adekunbi DA. The Possible Mechanisms through Which Dietary Protein Increases Renal Blood Flow and Glomerular Filtration Rate. Br J Med Med Res. 2015; 7(6): 458-469.

Eskuragarri: http://www.journalrepository.org/media/journals/BJMMR 12/2015/Feb/Aluko762015BJMM $\underline{R} 16214 . p d f$

7. Wakefield AP, House JD, Ogborn MR, Weiler HA, Aukema HM. A diet with $35 \%$ of energy from protein leads to kidney damage in female Sprague-Dawley rats. Br J Nutr. 2011; 106(5):65663. Eskuragarri: https://www.cambridge.org/core/journals/british-journal-ofnutrition/article/diet-with-35-of-energy-from-protein-leads-to-kidney-damage-in-femalespraguedawley-rats/9B91003F499906F19B52BA3FFCD67A9D

8. Jia Y, Hwang SY, House JD, Ogborn MR, Weiler HA, O K, Aukema HM. Long-term high intake of whole proteins results in renal damage in pigs. J Nutr. 2010; 140(9):1646-52. Eskuragarri: https://academic.oup.com/in/article/140/9/1646/4600299

9. Bankir L, Bouby N, Trinh-Trang-Tan MM, Ahloulay M, Promeneur D. Direct and indirect cost of urea excretion. Kidney Int. 1996; 49(6):1598-607. Eskuragarri: https://www.kidneyinternational.org/article/S0085-2538(15)59526-4/pdf

10. Hahn D, Hodson EM, Fouque D. Low protein diets for non-diabetic adults with chronic kidney disease. Cochrane Database Syst Rev. 2018 Urr 4;10:CD001892. Eskuragarri: https://www.cochranelibrary.com/cdsr/doi/10.1002/14651858.CD001892.pub4/full

11. Schwingshackl L, Hoffmann G. Comparison of high vs. normal/low protein diets on renal function in subjects without chronic kidney disease: a systematic review and meta-analysis. PLOS One. 2014; 22;9(5):e97656. Eskuragarri: https://www.ncbi.nlm.nih.gov/pmc/articles/PMC4031217/

12. Frank H, Graf J, Amann-Gassner U, Bratke R, Daniel H, Heemann U, Hauner H. Effect of shortterm high-protein compared with normal-protein diets on renal hemodynamics and associated variables in healthy young men. Am J Clin Nutr. 2009; 90(6):1509-1516. Eskuragarri: https://academic.oup.com/ajcn/article/90/6/1509/4598074

13. Møller G, Rikardt Andersen J, Ritz C, P Silvestre M, Navas-Carretero S, Jalo E, Christensen P, Simpson E, Taylor M, Martinez JA, Macdonald I, Swindell N, Mackintosh KA, Stratton G, Fogelholm M, Larsen TM, Poppitt SD, Dragsted LO, Raben A. Higher Protein Intake Is Not Associated with Decreased Kidney Function in Pre-Diabetic Older Adults Following a One-Year Intervention-A Preview Sub-Study. Nutrients. 2018; 10(1). Eskuragarri: https://www.ncbi.nlm.nih.gov/pmc/articles/PMC5793282/

14. Devries MC, Sithamparapillai A, Brimble KS, Banfield L, Morton RW, Phillips SM. Changes in Kidney Function Do Not Differ between Healthy Adults Consuming Higher- Compared with 
Lower- or Normal-Protein Diets: A Systematic Review and Meta-Analysis. J Nutr. 2018; 148(11):1760-1775.

Eskuragarri: $\underline{\text { https://www.ncbi.nlm.nih.gov/pmc/articles/PMC6236074/ }}$

15. Pomerantz A, Blachman-Braun R, Vital-Flores S, Berebichez-Fridman R, Aguilar-Mendoza JP, Lara-Villalón $D$. Protein supplement consumption and its possible association with kidney damage in Mexican elite athletes. Rev Med Inst Mex Seguro Soc. 2016; 54(1):42-7. Eskuragarri (esp): https://www.researchgate.net/publication/292154598 Protein supplement consumption a nd its possible association with kidney damage in Mexican elite athletes

16. Morton RW, Murphy KT, McKellar SR, Schoenfeld BJ, Henselmans M, Helms E, Aragon AA, Devries MC, Banfield L, Krieger JW, Phillips SM. A systematic review, meta-analysis and metaregression of the effect of protein supplementation on resistance training-induced gains in muscle mass and strength in healthy adults. Br J Sports Med. 2018; 52(6):376-384. Eskuragarri: https://www.ncbi.nlm.nih.gov/pmc/articles/PMC5867436/

17. Antonio J, Peacock CA, Ellerbroek A, Fromhoff B, Silver T. The effects of consuming a high protein diet $(4.4 \mathrm{~g} / \mathrm{kg} / \mathrm{d})$ on body composition in resistance-trained individuals. J Int Soc Sports Nutr. 2014;11:19.

Eskuragarri: https://www.ncbi.nlm.nih.gov/pmc/articles/PMC4022420/

18. Antonio J, Ellerbroek A, Silver T, Vargas L, Peacock C. The effects of a high protein diet on indices of health and body composition--a crossover trial in resistance-trained men. J Int Soc Sports Nutr. 2016; 13:3. Eskuragarri: https://www.ncbi.nlm.nih.gov/pmc/articles/PMC4715299/

19. Walser M. Effects of Protein Intake on Renal Function and on the Development of Renal Disease. Hemen: Institute of Medicine (US) Committee on Military Nutrition Research. The Role of Protein and Amino Acids in Sustaining and Enhancing Performance [Internet]. Washington (DC): National Academies Press (US); 1999 [Kontsulta 2019-02-11] [18 or.]. Eskuragarri: https://www.ncbi.nlm.nih.gov/books/NBK224634/

20. Antonio J, Ellerbroek A, Silver T, Vargas L, Tamayo A, Buehn R, Peacock CA. A High Protein Diet Has No Harmful Effects: A One-Year Crossover Study in Resistance-Trained Males. J Nutr Metab. 2016;2016:9104792.

Eskuragarri: https://www.ncbi.nlm.nih.gov/pmc/articles/PMC5078648/ 